\title{
Determinants of stomatal sluggishness in ozone-exposed deciduous tree species
}

\author{
Yasutomo Hoshika ${ }^{a}$, Giulia Carriero ${ }^{\mathrm{a}}$, Zhaozhong Feng ${ }^{\mathrm{b}}$, Yulong Zhang ${ }^{\mathrm{b}}$, Elena Paoletti ${ }^{\mathrm{a}, *}$ \\ a Institute of Plant Protection, National Research Council of Italy, Via Madonna del Piano, I-50019 Sesto Fiorentino, Italy \\ ${ }^{\mathrm{b}}$ State Key Laboratory of Urban and Regional Ecology, Research Center for Eco-Environmental Science, Chinese Academy of Sciences (CAS), 18 Shuangqing Road, Haidian District, \\ Beijing 100085, China
}

\section{H I G H L I G H T S}

- Our knowledge of ozone $\left(\mathrm{O}_{3}\right)$ effects on dynamic stomatal response is still limited.

- Determinants of $\mathrm{O}_{3}$-induced stomatal sluggishness were examined in deciduous tree species in open-top chambers.

- Ozone exposure slowed closing of stomata after leaf cutting.

- Stomatal sluggishness was well explained by stomatal $\mathrm{O}_{3}$ flux per net photosynthesis.

- Stomatal sluggishness depended both on ozone flux and on the capacity for detoxification or repair.

\section{A R T I C L E I N F O}

Article history:

Received 7 January 2014

Received in revised form 18 February 2014

Accepted 18 February 2014

Available online 12 March 2014

\section{Keywords:}

Tropospheric ozone

Stomatal response

Stomatal conductance

Stomatal sluggishness

\begin{abstract}
A B S T R A C T
Our knowledge of ozone effects on dynamic stomatal response is still limited, especially in Asian tree species. We thus examined ozone effects on steady-state leaf gas exchange and stomatal dynamics in three common tree species of China (Ailanthus altissima, Fraxinus chinensis and Platanus orientalis). Seedlings were grown and were exposed to three levels of ozone in open-top chambers $\left(42,69,100 \mathrm{nmol} \mathrm{mol}^{-1}\right.$ daylight average, from 09:00 to 18:00). At steady-state, ozone exposure induced an uncoupling of photosynthesis and stomatal conductance, as the former decreased while the latter did not. Dynamic stomatal response was investigated by cutting the leaf petiole after a steady-state stomatal conductance was reached. Ozone exposure increased stomatal sluggishness, i.e., slowed stomatal response after leaf cutting, in the following order of sensitivity, $F$. chinensis $>$ A. altissima $>P$. orientalis. A restriction of stomatal ozone flux reduced the ozone-induced sluggishness in P. orientalis. The ozone-induced impairment of stomatal control was better explained by stomatal ozone flux per net photosynthesis rather than by stomatal ozone flux only. This suggests that ozone injury to stomatal control depends both on the amount of ozone entering a leaf and on the capacity for biochemical detoxification or repair. Leaf mass per area and the density of stomata did not affect stomatal sluggishness.
\end{abstract}

(c) 2014 Elsevier B.V. All rights reserved.

\section{Introduction}

Tropospheric ozone $\left(\mathrm{O}_{3}\right)$ is recognized as a significant phytotoxic air pollutant and greenhouse gas (Bytnerowicz et al., 2007; Serengil et al., 2011). Ozone concentrations have been increasing in the northern hemisphere since the pre-industrial age (Akimoto, 2003; Vingarzan, 2004). Especially in East Asian countries, further increases in $\mathrm{O}_{3}$ concentrations are predicted throughout this century because of rapid economic growth (Ohara et al., 2007; Yamaji et al., 2008).

The phytotoxic nature of $\mathrm{O}_{3}$ may cause adverse effects on physiological and biochemical processes in tree species (Karnosky et al., 2003; Matyssek and Sandermann, 2003; Ashmore, 2005; Paoletti, 2007).

\footnotetext{
* Corresponding author. Tel.: + 390555225 591; fax: + 390555225666

E-mail address: e.paoletti@ipp.cnr.it (E. Paoletti).
}

There is still little information on effects of $\mathrm{O}_{3}$ on native plant species of Asia (Royal Society, 2008). Many studies on European and North American species reported that $\mathrm{O}_{3}$ may reduce carbon assimilation, and limit the growth of trees (e.g., Wittig et al., 2007, 2009). On the other hand, the effect of $\mathrm{O}_{3}$ on stomatal conductance is not straightforward (Mansfield, 1998; Paoletti and Grulke, 2005). Ozone has been reported to induce stomatal closure (Wittig et al., 2007). However, slower or less efficient stomatal control may occur, especially a weaker ability to close stomata, referred to as " $\mathrm{O}_{3}$-induced stomatal sluggishness" (Paoletti, 2005; Mills et al., 2009; Paoletti et al., 2009; Paoletti and Grulke, 2010; Hoshika et al., 2012a, 2013a,b; Dumont et al., 2013). Sluggishness may occur because $\mathrm{O}_{3}$ reduces stomatal sensitivity to abscisic acid (ABA) (Mills et al., 2009). This loss of stomatal response to $A B A$ is related to $\mathrm{O}_{3}$-induced ethylene emission (Wilkinson and Davies, 2010). Although our knowledge of the mechanism is still 
limited, such a reduced stomatal control may impair an efficient water use for plants (Sun et al., 2012).

Stomatal $\mathrm{O}_{3}$ flux is a crucial factor for the assessment of $\mathrm{O}_{3}$ effects, because stomata are the principal interface for entry of $\mathrm{O}_{3}$ into a leaf (Omasa et al., 2002; Karlsson et al., 2007; Mills et al., 2010). Stomatal response to environmental stimuli may be related to leaf anatomical traits such as stomatal density (e.g., Drake et al., 2013). Small stomata and their general association with high density of stomata provide the capacity for rapid response in the stomatal conductance of a leaf (Aasamaa et al., 2002; Hetherington and Woodward, 2003; Drake et al., 2013). This implies that fast response of stomata in leaves with high stomatal density and/or lower stomatal conductance during $\mathrm{O}_{3}$ exposure may result in less diffusion of $\mathrm{O}_{3}$ into a leaf, and may lead to a decrease in $\mathrm{O}_{3}$-induced injury (Pääkkönen et al., 1995).

Foliar $\mathrm{O}_{3}$ injury may also depend on the available resource for repair or biochemical $\mathrm{O}_{3}$ detoxification of a leaf (e.g., Tausz et al., 2007; Paoletti et al., 2008). Wieser et al. (2002) suggested that antioxidative capacity increased with increasing leaf mass per area (LMA). Inherent LMA may thus be roughly related to sensitivity to $\mathrm{O}_{3}$ stress (Bussotti, 2008; Zhang et al., 2012). Also Musselman and Minnick (2000) suggested that plant tolerance to $\mathrm{O}_{3}$ stress may depend on its photosynthetic capacity because detoxification and repair require energy (Noctor and Foyer, 1998). The sensitivity to foliar $\mathrm{O}_{3}$ injury may thus be explained by the ratio of stomatal $\mathrm{O}_{3}$ flux to net photosynthesis (Fredericksen et al., 1996; Kolb and Matyssek, 2001), indicating a balance between $\mathrm{O}_{3}$ exposure of mesophyll cells and availability of photosynthates for repair or detoxification.

In this study, we examined $\mathrm{O}_{3}$ effects on steady-state leaf gas exchange and dynamic stomatal response under severe water stress imposed by cutting a leaf in three tree species that are common in China. The objective of the study was to test whether the degree of $\mathrm{O}_{3}$-induced injury to stomatal control was related to stomatal density, LMA, stomatal $\mathrm{O}_{3}$ flux or the ratio of $\mathrm{O}_{3}$ flux to net photosynthesis.

\section{Materials and methods}

\subsection{Plant materials}

We used one-year-old seedlings of Ailanthus altissima (Mill.) Swingle, Fraxinus chinensis Roxb. and Platanus orientalis L. Before bud burst, bare rooted seedlings were planted in $20 \mathrm{~L}$ circular plastic pots on 31 March, 2013 and grown at ambient field condition (outdoors). Pots were filled with native light loamy soil. Seedlings with similar height and basal diameter were selected for this study and pre-adapted to open-top chamber conditions for 10 days before $\mathrm{O}_{3}$ fumigation. All plants were watered at field capacity at 1-3 day intervals to avoid water stress.

\section{2. $\mathrm{O}_{3}$ treatments}

The experiment was carried out in three open-top chambers (OTC, octagonal base, $12.5 \mathrm{~m}^{2}$ of growth space and $3.0 \mathrm{~m}$ of height) in Changping $\left(40^{\circ} 19^{\prime} \mathrm{N}, 116^{\circ} 13^{\prime} \mathrm{E}\right)$, Northwest Beijing with warm temperate and semi-humid continental climate. The annual mean temperature is $11.8{ }^{\circ} \mathrm{C}$, and total precipitation is $550 \mathrm{~mm}$. All seedlings were exposed to the following treatments for three months with a daily maximum of 9 h (from 09:00 to 18:00) when there was no rain, fog, mist or dew: nonfiltered ambient air (NF, averaged $\mathrm{O}_{3}$ concentration of $42 \mathrm{nmol} \mathrm{mol}{ }^{-1}$ from 09:00 to 18:00), NF supplied with $40 \mathrm{nmol} \mathrm{mol} \mathrm{m}^{-1}$ of $\mathrm{O}_{3}$ ( $\mathrm{NF}+40$, averaged $\mathrm{O}_{3}$ concentration of $69 \mathrm{nmol} \mathrm{mol} \mathrm{m}^{-1}$ from 09:00 to 18:00), and NF supplied with $80 \mathrm{nmol} \mathrm{mol} \mathrm{m}^{-1}$ of $\mathrm{O}_{3}\left(\mathrm{NF}+80\right.$, averaged $\mathrm{O}_{3}$ concentration of $100 \mathrm{nmol} \mathrm{mol}^{-1}$ from 09:00 to 18:00). Ozone was generated from pure oxygen by an $\mathrm{O}_{3}$ generator (HY003, Chuangcheng Co., Jinan, China). The concentrations of $\mathrm{O}_{3}$ in the OTCs were continuously monitored at approximately $10 \mathrm{~cm}$ above the plant canopy using a $\mathrm{UV}$ absorption $\mathrm{O}_{3}$ analyzer
(Model 49i-Thermo, USA). The monitors were calibrated by a 49iPS calibrator (Thermo Scientific, USA) before the experiment and once per month during the experiment. The chambers were turned off in the evening and the door was opened to allow for dew formation. Four or five potted plants per each tree species were set in each OTC. There was no replication of $\mathrm{O}_{3}$ treatments. In order to eliminate the positional and chamber effects (Potvin and Tardif, 1988), the plant positions were changed every week within each OTC, and all seedlings were switched between chambers every month, according to Feng et al. $(2008,2011)$.

\subsection{Measurements of leaf traits and gas exchange}

Measurements of leaf gas exchange were carried out with a portable infra-red gas-analyzer (Model 6400, Li-Cor Instruments, Lincoln, $\mathrm{NE}$, USA), at controlled value of leaf temperature $\left(30^{\circ} \mathrm{C}\right)$, leaf-to-air vapor pressure deficit (1.5 $\mathrm{kPa})$, saturating light $\left(1500 \mu \mathrm{mol} \mathrm{m} \mathrm{m}^{-2} \mathrm{~s}^{-1}\right.$ of PPFD, photosynthetic photon flux density) and ambient $\mathrm{CO}_{2}$ concentration $\left(400 \mu \mathrm{mol} \mathrm{mol}^{-1}\right)$ from 8 to 14 August, 2013. Four or five plants per each $\mathrm{O}_{3}$ treatment were used. A fully expanded sun leaf (leaf order: 4 th to 6 th in a shoot) was selected as a target. When stomatal conductance reached the equilibrium under constant light at $1500 \mu \mathrm{mol}$ $\mathrm{m}^{-2} \mathrm{~s}^{-1}$, the methodology described by Paoletti (2005) was applied to assess dynamic variations of stomatal conductance after cutting the leaf petiole (Fig. 1). Data were logged at $1 \mathrm{~min}$ intervals for $30 \mathrm{~min}$ after cutting the petiole. Two phases of stomatal response were observed (Fig. 1). At first, stomatal conductance showed an increase called as the transient "wrong-way response" (WWR) (Powles et al., 2006). This transient increase is due to a difference in turgor pressure between guard cell and epidermal cells. Subsequently, stomatal conductance decreased with increasing leaf water stress. In the present study, the magnitude of WWR and time for $50 \%$ decrease of stomatal conductance were recorded. All gas exchange measurements were performed from 9:00 to 12:00 to avoid the midday depression of stomatal conductance (cf. Zhang and Gao, 1999).

After measurement of leaf gas exchange, the same leaves were analyzed for determining the leaf mass per unit area (LMA). Three leaf disks (12 mm diameter) per measured leaf were punched out and dried in an oven at $70{ }^{\circ} \mathrm{C}$ for 1 week and then weighed. LMA was calculated as the ratio of dry mass to area of the leaf disks. The stomatal density was determined by the SUMP method (Koike et al., 1998), which involves making a replica of the abaxial leaf surface using a celluloid sheet (Universal Micro-printing, SUMP, Tokyo, Japan). Stomata were counted at 5-7 locations, randomly chosen from interveinal fields, of a total area of $0.4 \mathrm{~mm}^{2}$, under a light microscope.

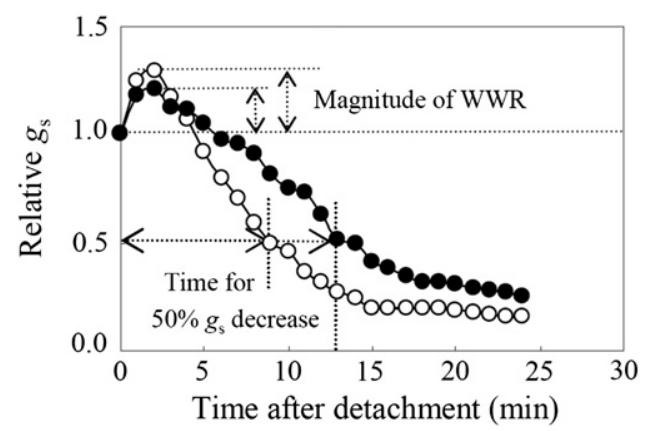

Fig. 1. Example of time course of stomatal conductance $\left(g_{\mathrm{s}}\right)$ after severing a $F$. chinensis leaf at time zero (open circle: NF, closed circle: $N F+80$ ), with calculation of wrong way response (WWR) magnitude, and time for $50 \%$ decrease in stomatal conductance with increasing leaf water stress. 


\subsection{Stomatal ozone flux}

Stomatal $\mathrm{O}_{3}$ flux was estimated from stomatal conductance to water vapor $\left(g_{s}\right)$, employing the water vapor surrogate method (Emberson et al., 2000; Hoshika et al., 2012b,c). This method assumes the $\mathrm{O}_{3}$ concentration inside leaves to be close to zero (Laisk et al., 1989; Omasa et al., 2002). Stomatal conductance to $\mathrm{O}_{3}$ can be then derived from $g_{\mathrm{s}}$ and ambient $\mathrm{O}_{3}$ concentrations multiplied by 0.613 , i.e., the ratio of diffusivities between $\mathrm{O}_{3}$ and water vapor (Wieser et al., 2002). In the present study, we used the mean $\mathrm{O}_{3}$ concentration during daytime (09:00-18:00) in each treatment. Finally, stomatal $\mathrm{O}_{3}$ flux per net photosynthetic rate was calculated at steady-state conditions.

\subsection{Statistical analysis}

The statistical unit was the single plant. Two-way analysis of variance (ANOVA) was used to assess the effects of species and $\mathrm{O}_{3}$ treatments on leaf gas exchange parameters. Data were checked for normal distribution (Kolmogorov Smirnov D test) and homogeneity of variance (Levene's test). A simple linear correlation was used to test the relation of the parameters of $\mathrm{O}_{3}$-induced stomatal sluggishness with leaf traits (i.e., LMA or stomatal density) or indices of $\mathrm{O}_{3}$ flux (i.e., stomatal $\mathrm{O}_{3}$ flux, or stomatal $\mathrm{O}_{3}$ flux per net photosynthetic rate). Species-specific differences of the relationship of $\mathrm{O}_{3}$-induced stomatal sluggishness were tested by analysis of covariance (ANCOVA) with indices of $\mathrm{O}_{3}$ flux as covariate. Results were considered significant at $p<0.05$. All statistical analyses were performed with SPSS software (20.0, SPSS, Chicago, USA).

\section{Results}

\subsection{Leaf traits}

Enhanced ozone concentrations did not affect stomatal density for any of the three species (data not shown). Average stomatal density was $211 \mathrm{~mm}^{-2}$ in A. altissima, $116 \mathrm{~mm}^{-2}$ in F. chinensis, and $118 \mathrm{~mm}^{-2}$ in $P$. orientalis. There was no difference in LMA between $\mathrm{O}_{3}$ treatments for any species (data not shown). Average LMA was $44.9 \mathrm{~g} \mathrm{~m}^{-2}$ in A. altissima, $53.6 \mathrm{~g} \mathrm{~m}^{-2}$ in F. chinensis, and $40.7 \mathrm{~g} \mathrm{~m}^{-2}$ in P. orientalis.

3.2. Steady-state leaf gas exchange and dynamic stomatal response after leaf excision

Ozone exposure induced a decline of steady-state net photosynthetic rate (Fig. 2). Lower net photosynthesis was found in enhanced $\mathrm{O}_{3}$ treatments compared to $\mathrm{NF}(-17 \%$ in A. altissima, $-28 \%$ in $F$. chinensis, and $-1 \%$ in $P$. orientalis in NF $+40 ;-29 \%$ in A. altissima, $-43 \%$ in $F$. chinensis, and $-35 \%$ in $P$. orientalis in $\mathrm{NF}+80$ ). Stomatal conductance did not show significant difference between $\mathrm{O}_{3}$ treatments (Fig. 2).

Magnitude of WWR was not affected by $\mathrm{O}_{3}$ (data not shown). Time for $50 \%$ decrease of stomatal conductance in NF was $5.5 \pm 0.6 \mathrm{~min}$ in A. altissima, $7.5 \pm 0.9 \mathrm{~min}$ in $F$. chinensis, and $6.0 \pm 0.4 \mathrm{~min}$ in $P$. orientalis (Fig. 3). Increase in the time elapsed for $50 \%$ decrease of stomatal conductance was found especially in NF +80 compared to $\mathrm{NF}(+50 \%$ in A. altissima, $+57 \%$ in $F$. chinensis, and $+17 \%$ in P. orientalis).

There was no significant relationship between time for $50 \%$ decrease of stomatal conductance after cutting a leaf and leaf traits (stomatal density or LMA: Fig. 4A,B). Time for $50 \%$ decrease of stomatal conductance increased with increasing stomatal $\mathrm{O}_{3}$ flux (Fig. 4C), and with increasing ratio of stomatal $\mathrm{O}_{3}$ flux to net photosynthesis (Fig. 4D) in A. altissima and $F$. chinensis. The relationships among $\mathrm{O}_{3}$-induced stomatal sluggishness and indices of $\mathrm{O}_{3}$ flux (stomatal $\mathrm{O}_{3}$ flux or the ratio of stomatal $\mathrm{O}_{3}$ flux to net photosynthesis) differed between these two

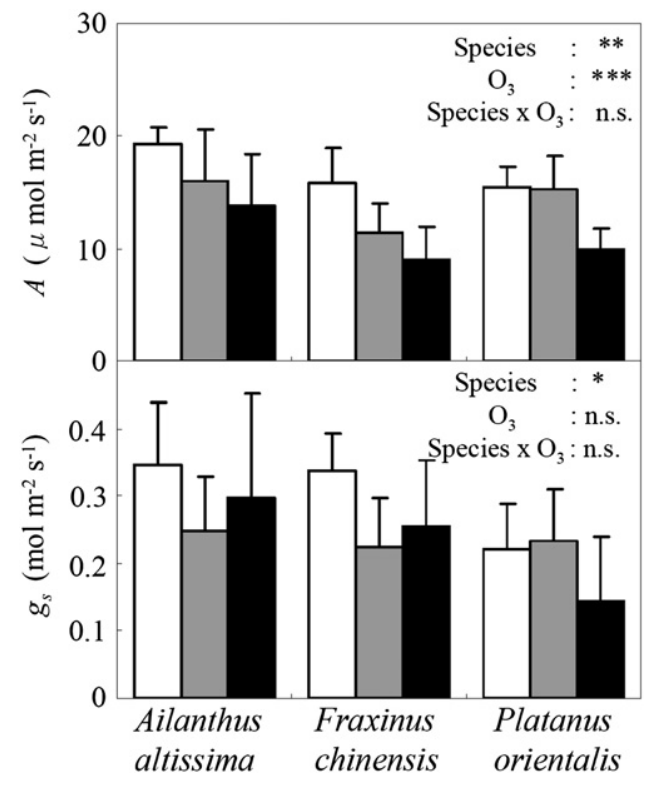

Fig. 2. Effect of chronic ozone exposure at three levels (NF: non-filtered ambient air, shown as white bar; NF +40 : NF supplied with $40 \mathrm{nmol} \mathrm{mol}^{-1}$ of ozone, shown as gray bar; NF +80 : NF supplied with $80 \mathrm{nmol} \mathrm{mol}^{-1}$ of ozone, shown as black bar) on steady-state net photosynthetic rate $(A)$ and stomatal conductance $\left(g_{s}\right)$ in 1 year old seedlings of three Chinese tree species. Data are means $(\mathrm{N}=4-5$ plants $)+\mathrm{SD}$. Two-way ANOVA: ${ }^{*} p<0.05 ;{ }^{* *} p<0.01{ }^{* * *} p<0.001$; n.s. indicates no significance.

species (Fig. 4C,D). Higher y-intercepts in those relationships were recorded in $F$. chinensis compared to A. altissima $(p<0.01)$.

\section{Discussion}

Ozone exposure caused a decrease in the steady-state values of net photosynthesis in all three species, while no difference in stomatal conductance was found (Fig. 2). This response of stomatal conductance is in contrast with a meta-analysis of physiological responses to $\mathrm{O}_{3}$ by trees (Wittig et al., 2007). Stomatal conductance is generally regulated so as to maintain the ratio of internal $\mathrm{CO}_{2}$ concentration to ambient $\mathrm{CO}_{2}$ concentration (Lambers et al., 2008). At a moderate level of chronic $\mathrm{O}_{3}$ exposure, $\mathrm{O}_{3}$-induced decline of photosynthetic capacity may therefore cause stomatal closure (Reich, 1987; Farage and Long, 1995; Heath and Taylor, 1997). However, free-air $\mathrm{O}_{3}$ exposure experiments showed that such $\mathrm{O}_{3}$-induced stomatal closure was diminished in European and Seibold's beech (Fagus sylvatica and Fagus crenata, respectively) during the late growing season, although $\mathrm{O}_{3}$ decreased photosynthetic capacity (Löw et al., 2007; Hoshika et al., 2013b). The observation

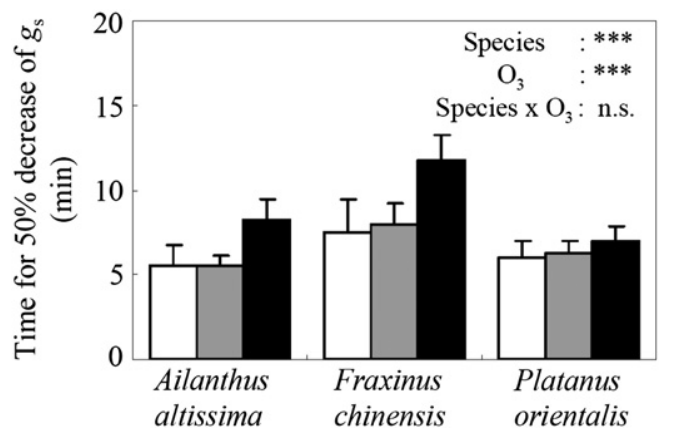

Fig. 3. Effect of chronic ozone exposure at three levels (NF: non-filtered ambient air, shown as white bar; NF +40 : NF supplied with $40 \mathrm{nmol} \mathrm{mol}^{-1}$ of ozone, shown as gray bar; NF +80 : NF supplied with $80 \mathrm{nmol} \mathrm{mol}{ }^{-1}$ of ozone, shown as black bar) on time for $50 \%$ decrease of stomatal conductance $\left(g_{s}\right)$ after severing a leaf in 1 year old seedlings of three Chinese tree species. Data are means ( $\mathrm{N}=4-5$ plants $)+\mathrm{SD}$. Two-way ANOVA: **** $p<0.001 ;$ n.s. indicates no significance. 

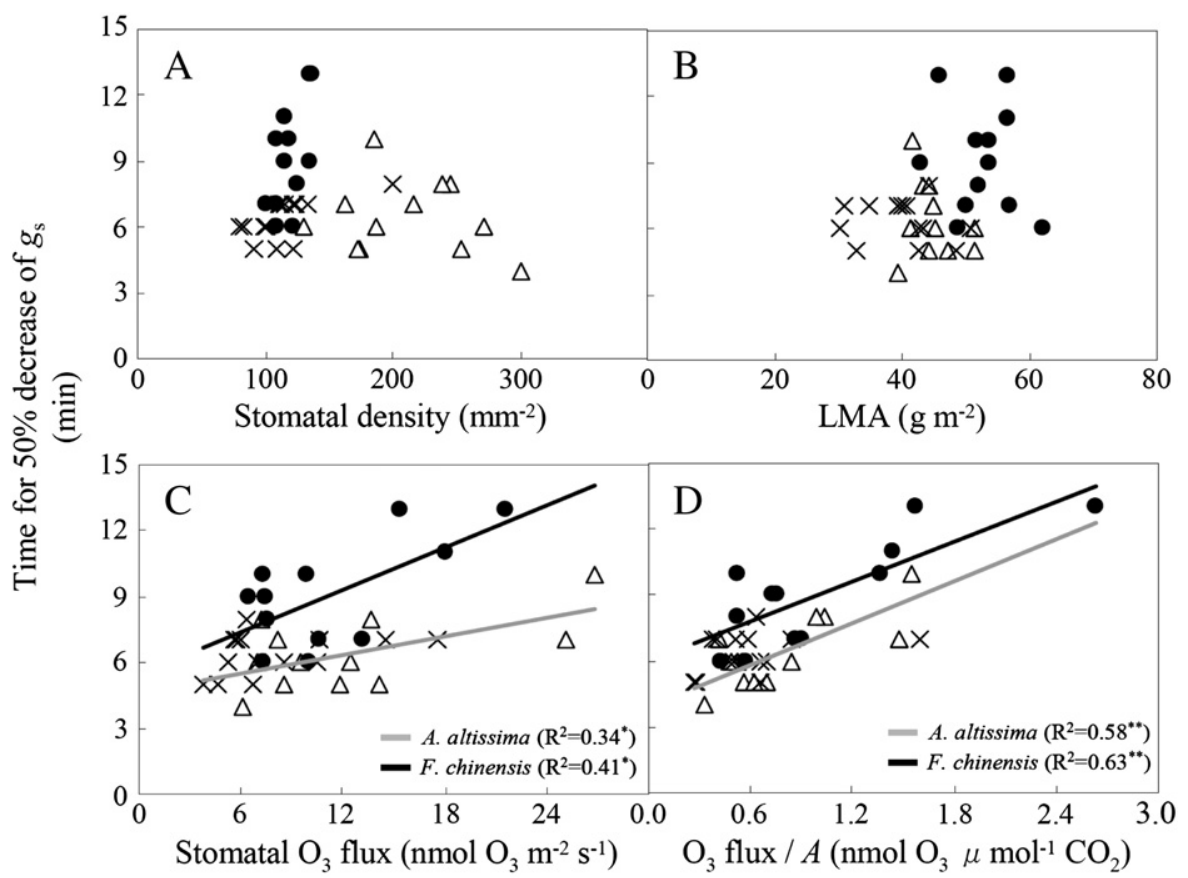

$\Delta$ Ailanthus altissima $\bullet$ Fraxinus chinensis $\times$ Platanus orientalis

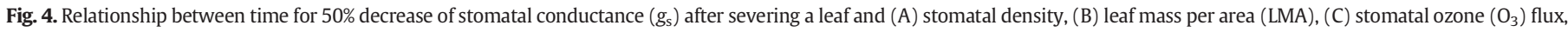

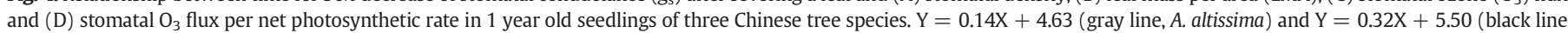

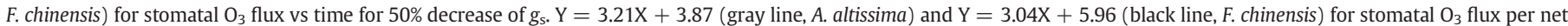

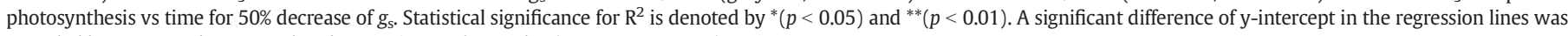
recorded between $A$. altissima and $F$. chinensis in panels C and D (ANCOVA, $p<0.01$ ).

here implies a decoupling of stomatal conductance and photosynthesis after $\mathrm{O}_{3}$ exposure.

Enhanced $\mathrm{O}_{3}$ exposure caused slower closing response of stomata to the severe water stress imposed by excision of a leaf in all three tree species (Fig. 3). Similar findings were reported in previous studies (e.g., Paoletti, 2005; Mills et al., 2009; Paoletti and Grulke, 2010; Hoshika et al., 2012a). Maier-Maercker (1989) suggested that such slower stomatal response might be explained by delignification of the guard cell and subsidiary cells as recorded in ozonated Picea abies. No change in guard cell wall lignification, however, was observed in ozone-injured manna ash (Fraxinus ornus) leaves showing stomatal sluggishness (Paoletti et al., 2009). In manna ash, such slower stomatal responses were considered as accelerated senescence in the cell physiological processes (Paoletti et al., 2009). Mills et al. (2009) found that $\mathrm{O}_{3}$ reduced stomatal sensitivity to $\mathrm{ABA}$. Wilkinson and Davies (2010) suggested that the loss of stomatal response to ABA may be related to $\mathrm{O}_{3}$-induced ethylene emissions. However, the mechanisms of the sluggish response of stomata caused by $\mathrm{O}_{3}$ are still under investigation. We thus investigated whether leaf traits, i.e. stomatal density and LMA, can affect sluggishness of stomata.

There was no significant relationship between stomatal sluggishness and stomatal density (Fig. 4B). The higher stomatal density in A. altissima translated into a slightly faster response of stomata in NF than those in the other two species (Fig. 3). Our result however indicated that observed slightly faster stomatal responses associated with higher stomatal density in leaves were not enough to reduce $\mathrm{O}_{3}$ injury to stomatal control.

The degree of $\mathrm{O}_{3}$-induced impairment of stomatal control was greater in leaves with higher stomatal $\mathrm{O}_{3}$ flux in $A$. altissima and $\mathrm{F}$. chinensis (Fig. 4C). No significant relationship was found in $P$. orientalis. Interestingly, $P$. orientalis showed relatively lower stomatal $\mathrm{O}_{3}$ flux than the other two species (Fig. 4C), and showed the lowest increase in time for $50 \%$ decrease in stomatal conductance after cutting a leaf even under elevated $\mathrm{O}_{3}$ condition (Fig. 3). This may be interpreted as more efficient limitation of stomatal $\mathrm{O}_{3}$ flux in $P$. orientalis than in the other two species. Such capacity for avoidance of $\mathrm{O}_{3}$-induced stress by smaller $\mathrm{O}_{3}$ influx in $P$. orientalis may contribute to reduced injury to stomatal control under elevated $\mathrm{O}_{3}$. In addition, $F$. chinensis showed higher $y$-intercept in the relationship between stomatal sluggishness and indices of $\mathrm{O}_{3}$ flux (i.e., stomatal $\mathrm{O}_{3}$ flux, or stomatal $\mathrm{O}_{3}$ flux per net photosynthetic rate) compared to that in A. altissima. In fact, the time for $50 \%$ decrease of stomatal conductance (NF $+80 \mathrm{vs.} \mathrm{NF}$ ) was greater in F. chinensis $(+57 \%)$ than in the other species $(+50 \%$ in A. altissima, and $+17 \%$ in P. orientalis). This indicates the following order of sensitivity of $\mathrm{O}_{3}$-induced stomatal sluggishness, $F$. chinensis $>$ A. altissima $>P$. orientalis.

The ratio of stomatal $\mathrm{O}_{3}$ flux to net photosynthesis, which is an index of both $\mathrm{O}_{3}$ exposure of mesophyll cells and availability of photosynthates for repair or detoxification, was the best parameter explaining the impairment of stomatal control induced by $\mathrm{O}_{3}$ (Fig. 4D). Fredericksen et al. (1996) similarly reported that greater foliar $\mathrm{O}_{3}$ flux per net photosynthesis in shade leaves was related to the degree of visible foliar injury in black cherry (Prunus serotina) trees. This suggests that the sensitivity to the $\mathrm{O}_{3}$-induced impairment of stomatal control is related not only to diffusion of $\mathrm{O}_{3}$ into leaves but also to biochemical detoxification capacity or repair. Biochemical detoxification capacity may also be related to LMA because greater LMA implies a higher density of mesophyll tissues, suggesting a higher capability of repair or detoxification (Wieser et al., 2002). However, $\mathrm{O}_{3}$-induced sluggish response of stomata did not show any relation with LMA (data not shown). Watanabe et al. (2013) reported that Siebold's beech (Fagus crenata) showed much greater $\mathrm{O}_{3}$ injury to photosynthetic traits than that in deciduous oak (Quercus mongolica var. crispula), even though both species had similar LMA. Our results suggest that physiological leaf traits 
affect $\mathrm{O}_{3}$-induced stomatal sluggishness more than anatomical leaf traits, although a relatively small range of LMA among the three species was examined here.

In conclusion, the present study demonstrated that enhanced $\mathrm{O}_{3}$ exposure slowed the stomatal dynamics in three tree species of China. This effect was species-specific, being greater in $F$. chinensis and smaller in $P$. orientalis. The degree of $\mathrm{O}_{3}$-induced impairment of stomatal control was related to stomatal $\mathrm{O}_{3}$ flux. A restriction of stomatal $\mathrm{O}_{3}$ flux reduced $\mathrm{O}_{3}$ injury to stomatal control in P. orientalis. Yamaji et al. (2008) predicted further increase in $\mathrm{O}_{3}$ concentration in East Asian countries in 2020 . Climate change brings about further risk of drought and flooding (Bytnerowicz et al., 2007). This $\mathrm{O}_{3}$-induced loss of stomatal function may therefore enhance both leaf water loss and stomatal $\mathrm{O}_{3}$ flux under predicted $\mathrm{O}_{3}$ pollution (e.g., Hayes et al., 2012). The present study also found that the $\mathrm{O}_{3}$-induced sluggish response of stomata was better explained by stomatal $\mathrm{O}_{3}$ flux per net photosynthesis rather than by stomatal $\mathrm{O}_{3}$ flux only, supporting the use of carbon assimilation as a surrogate for tolerance to $\mathrm{O}_{3}$ stress including a capacity for repair and detoxification (Paoletti et al., 2008). The concept of "effective $\mathrm{O}_{3}$ dose" reflecting plant sensitivity to unit of stomatal $\mathrm{O}_{3}$ flux may contribute to further development of our knowledge into the mechanisms of plant response to $\mathrm{O}_{3}$-induced stress (Wieser et al., 2002; Musselman et al., 2006; Matyssek et al., 2008).

\section{Acknowledgments}

We are grateful for financial support by a grant-in-aid from the Japanese Society for Promotion of Science (Young Scientists for research abroad) and the Hundred Talents Program, Chinese Academy of Science. We also thank Dr. Enzhu Hu from Chinese Academy of Science for the kind help in the calculation of ozone concentrations.

\section{References}

Aasamaa K, Sõber A, Hartung W, Niinemets U. Rate of stomatal opening, shoot hydraulic conductance and photosynthetic characteristics in relation to leaf abscisic acid concentration in six temperate deciduous trees. Tree Physiol 2002;22:267-76.

Akimoto H. Global air quality and pollution. Science 2003;302:1716-9.

Ashmore MR. Assessing the future global impacts of ozone on vegetation. Plant Cell Environ 2005;28:949-64

Bussotti F. Functional leaf traits, plant communities and acclimation processes in relation to oxidative stress in trees: a critical overview. Glob Chang Biol 2008:14:2727-39.

Bytnerowicz A, Omasa K, Paoletti E. Integrated effects of air pollution and climate change on forests: a northern hemisphere perspective. Environ Pollut 2007;147:438-45.

Drake PL, Froend RH, Franks PJ. Smaller, faster stomata: scaling of stomatal size, rate of response, and stomatal conductance. J Exp Bot 2013;64:495-505.

Dumont J, Spicher F, Montpied P, Dizengremel P, Jolivet Y, Le Thiec D. Effects of ozone on stomatal response to environmental parameters (blue light, red light, $\mathrm{CO}_{2}$ and vapour pressure deficit) in three Populus deltoides $\times$ Populus nigra genotypes. Environ Pollut 2013;173:85-96.

Emberson LD, Ashmore MR, Cambridge HM, Simpson D, Tuovinen J-P. Modelling stomatal ozone flux across Europe. Environ Pollut 2000;109:403-13.

Farage PK, Long SP. An in vivo analysis of photosynthesis during short-term $\mathrm{O}_{3}$ exposure in three contrasting species. Photosynth Res 1995;43:11-8.

Feng ZZ, Zeng HQ, Wang XK, Zheng QW, Feng ZW. Sensitivity of Metasequoia glyptostroboides to ozone stress. Photosynthetica 2008;46:463-5.

Feng Z, Niu J, Zhang W, Wang X, Yao F, Tian Y. Effects of ozone exposure on sub-tropical evergreen Cinnamomum camphora seedlings grown in different nitrogen loads. Trees - Struct Funct 2011;25:617-25.

Fredericksen TS, Kolb TE, Skelly JM, Steiner KC, Joyce BJ, Savage JE. Light environment alters ozone uptake per net photosynthetic rate in black cherry trees. Tree Physio 1996;16:485-90.

Hayes F, Wagg S, Mills G, Wilkinson S, Davies W. Ozone effects in a drier climate: implications for stomatal fluxes of reduced stomatal sensitivity to soil drying in a typical grassland species. Glob Chang Biol 2012;18:948-59.

Heath RL, Taylor GE. Physiological processes and plant responses to ozone exposure. In: Sandermann H, Wellburn AR, Heath RL, editors. Forest decline and ozone. Ecological studiesBerlin: Springer-Verlag; 1997. p. 317-68.

Heatherington AM, Woodward FI. The role of stomata in sensing and driving environmental change. Nature 2003:424:901-8.

Hoshika Y, Paoletti E, Omasa K. Parameterization of Zelkova serrata stomatal conductance model to estimate stomatal ozone uptake in Japan. Atmos Environ 2012a;55:271-8.

Hoshika Y, Watanabe M, Inada N, Koike T. Ozone-induced stomatal sluggishness develops progressively in Siebold's beech (Fagus crenata). Environ Pollut 2012b;166:152-6.
Hoshika Y, Watanabe M, Inada N, Koike T. Modeling of stomatal ozone conductance for estimating ozone uptake of Fagus crenata under experimentally enhanced free-air ozone exposure. Water Air Soil Pollut 2012c;223:3893-901.

Hoshika Y, Omasa K, Paoletti E. Both ozone exposure and soil water stress are able to induce stomatal sluggishness. Environ Exp Bot 2013a;88:19-23.

Hoshika Y, Watanabe M, Inada N, Koike T. Model-based analysis of avoidance of ozone stress by stomatal closure in Siebold's beech (Fagus crenata). Ann Bot 2013b;112: $1149-58$.

Karlsson PE, Braun S, Broadmeadow M, Elvira S, Emberson L, Gimeno BS, Le Thiec D, Novak K, Oksanen E, Schaub M, Uddling J, Wilkinson M. Risk assessments for forest trees: the performance of the ozone flux versus the AOT concepts. Environ Pollut 2007:146:608-16.

Karnosky D, Percy KE, Chappelka AH, Simpson C, Pikkarainen J. Air pollution, global change and forests in the new millennium. Oxford, UK: Elsevier; 2003.

Koike T, Watanabe T, Toda H, Haibara K. Morphological diversity of stomata of representative broadleaved trees in a temperate region: detection with the Sump method. For Resour Environ 1998;36:55-63.

Kolb TE, Matyssek R. Limitation and perspectives about scaling ozone impacts in trees. Environ Pollut 2001;115:373-93.

Laisk A, Kull O, Moldau H. Ozone concentration in leaf intercellular air spaces is close to zero. Plant Physiol 1989;90:1163-7.

Lambers H, Chapin III FS, Pons TL. Plant physiological ecology. 2nd-edition. New York: Springer-Verlag; 2008 [640 pp.].

Löw M, Häberle KH, Warren CR, Matyssek R. $\mathrm{O}_{3}$ flux-related responsiveness of photosynthesis, respiration, and stomatal conductance of adult Fagus sylvatica to experimentally enhanced free-air $\mathrm{O}_{3}$ exposure. Plant Biol 2007:9:197-206.

Maier-Maercker U. Delignification of subsidiary and guard cell walls of Picea abies (L.) Karst. by fumigation with ozone. Trees 1989;3:57-64.

Mansfield TA. Stomata and plant water relations: does air pollution create problems? Environ Pollut 1998;101:1-11.

Matyssek R, Sandermann H. Impact of ozone on trees: an ecophysiological perspective. In: Esser K, Lüttge U, Beyschlag W, Hellwig F, editors. An ecophysiological perspective. Progress in botanyBerlin Heidelberg: Springer-Verlag; 2003. p. 349-404.

Matyssek R, Sandermann H, Wieser G, Booker F, Cieslik S, Musselman R, Ernst D. The challenge of making ozone risk assessment for forest trees more mechanistic. Environ Pollut 2008;156:567-82.

Mills G, Hayes F, Wilkinson S, Davies WJ. Chronic exposure to increasing background ozone impairs stomatal functioning in grassland species. Glob Chang Biol 2009;15: 1522-33.

Mills G, Pleijel H, Büker P, Braun S, Emberson LD, Harmens H, Hayes F, Simpson D, Grünhage L, Karlsson PE, Danielsson H, Bermejo V, Gonzalez Fernandez I. Mapping critical levels for vegetation. Revision undertaken in summer 2010 to include new flux-based critical levels and response functions for ozone. Mapping manual 2004. International cooperative programme on effects of air pollution on natural vegetation and crops; 2010.

Musselman RC, Minnick TJ. Nocturnal stomatal conductance and ambient air quality standards for ozone. Atmos Environ 2000:34:719-33.

Musselman RC, Lefohn AS, Massman WJ, Heath RL. A critical review and analysis of the use of exposure- and flux-based ozone indices for predicting vegetation effects. Atmos Environ 2006;40:1869-88.

Noctor G, Foyer CH. Ascorbate and glutathione: keeping active oxygen under control. Annu Rev Plant Physiol Plant Mol Biol 1998;49:249-79.

Ohara T, Akimoto H, Kurokawa J, Horii N, Yamaji K, Yan X, Hatasaka T. An Asian emission inventory of anthropogenic emission sources for the period 1980-2020. Atmos Chem Phys 2007; 7:419-4444.

Omasa K, Saji H, Youssefian S, Kondo K. Air pollution and plant biotechnology. Tokyo: Springer-Verlag; 2002 [455 pp.].

Pääkkönen E, Metsärinne S, Holopainen T, Kärenlampi L. The ozone sensitivity of birch (Betula pendula) in relation to the developmental stage of leaves. New Phytol 1995;132:145-54.

Paoletti E. Ozone slows stomatal response to light and leaf wounding in a Mediterranean evergreen broadleaf, Arbutus unedo. Environ Pollut 2005;134:439-45.

Paoletti E. Ozone impacts on forests. CAB reviews: perspectives in agriculture, veterinary science. Nutrition Natural Resources 2007;2(No. 68). [13 pp.]

Paoletti E, Grulke NE. Does living in elevated $\mathrm{CO}_{2}$ ameliorate tree response to ozone? A review on stomatal responses. Environ Pollut 2005;137:483-93.

Paoletti E, Grulke NE. Ozone exposure and stomatal sluggishness in different plant physiognomic classes. Environ Pollut 2010;158:2664-71.

Paoletti E, Ranieri A, Lauteri M. Moving toward effective ozone flux assessment. Environ Pollut 2008;156:16-9.

Paoletti E, Contran N, Bernasconi P, Gunthardt-Goerg MS, Vollenweider P. Structural and physiological responses to ozone in Manna ash (Fraxinus ornus L.) leaves of seedlings and mature trees under controlled and ambient conditions. Sci Total Environ 2009; 407:1631-43

Potvin C, Tardif S. Sources of variability and experimental design in growth chambers. Funct Ecol 1988;2:123-30.

Powles JE, Buckley TN, Nicotra AB, Farquhar GD. Dynamics of stomatal water relations following leaf excision. Plant Cell Environ 2006:29:981-92.

Reich PB. Quantifying plant response to ozone: a unifying theory. Tree physiol 1987;3: 63-91.

Royal Society. Ground-level ozone in the 21st century: 1 future trends, impacts and policy implications. Sci Policy Rep 2008;15(08).

Serengil Y, Augustaitis A, Bytnerowicz A, Grulke N, Kozovitz AR, Matyssek R, Müller-Starck G, Schaub M, Wieser G, Coskun AA, Paoletti E. Adaptation of forest ecosystems to air pollution and climate change: a global assessment on research priorities. iForest - Biogeosci For 2011;4:44-8. 
Sun G, McLaughlin SB, Porter JH, Uddling J, Mulholland PJ, Adams MB, Pederson N. Interactive influences of ozone and climate on streamflow of forested watersheds. Glob Chang Biol 2012;18:3395-409.

Tausz M, Grulke NE, Wieser G. Defense and avoidance of ozone under global change. Environ Pollut 2007;147:525-31.

Vingarzan R. A review of surface ozone background levels and trends. Atmos Environ 2004;38:3431-42.

Watanabe M, Hoshika Y, Inada N, Wang X, Mao O, Koike T. Photosynthetic traits of Siebold's beech and oak saplings grown under free air ozone exposure. Environ Pollut 2013;174:50-6.

Wieser G, Tegischer K, Tausz M, Häberle K-H, Grams TEE, Matyssek R. Age effects on Norway spruce (Picea abies) susceptibility to ozone uptake: novel approach relating stress avoidance to defense. Tree Physiol 2002;22:583-90.

Wilkinson S, Davies W. Drought, ozone, ABA and ethylene: new insights from cell to plant community. Plant Cell Environ 2010;33:510-25.
Wittig VE, Ainsworth EA, Long SP. To what extent do current and projected increases in surface ozone affect photosynthesis and stomatal conductance of trees? A meta-analytic review of the last 3 decades of experiments. Plant Cell Environ 2007;30:1150-62.

Wittig VE, Ainsworth EA, Naidu SL, Karnosky DF, Long SP. Quantifying the impact of current and future tropospheric ozone on tree biomass, growth, physiology and biochemistry: a quantitative meta-analysis. Glob Chang Biol 2009;15:394-424.

Yamaji K, Ohara T, Uno I, Kurokawa J, Pochanart P, Akimoto H. Future prediction of surface ozone over east Asia using models-3 community multiscale air quality modeling system and regional emission inventory in Asia. J Geophys Res 2008;113:D08306. http://dx.doi.org/10.1029/2007JD008663.

Zhang S, Gao R. Diurnal changes of gas exchange, chlorophyll fluorescence, and stomata aperture of hybrid poplar clones subjected to midday light stress. Photosynthetica 1999;37:559-71.

Zhang W, Feng Z, Wang X, Niu J. Response of native broadleaved woody species to elevated ozone in subtropical China. Environ Pollut 2012;163:149-57. 